Article

\title{
The Bodily Discourse in Modern Chinese Buddhism-Asceticism and Its Presentation in Buddhist Periodicals
}

\author{
Lianghao LuDㅛ \\ University of Pittsburgh, 4200 Fifth Ave, Pittsburgh, PA 15260, USA; lil76@pitt.edu
}

Received: 18 June 2020; Accepted: 28 July 2020; Published: 4 August 2020

\begin{abstract}
This article focuses on accounts of bodily asceticism published in Buddhist periodicals in Republican China (1912-1949) in order to explore the mentality and motivation of publicly presenting this seemingly fanatic and backward tradition in an era marked by modernization. By zeroing in on practices of self-immolation, bodily mutilation, and blood writing, as presented in periodicals advocating either reform or preservation of Buddhist tradition, the article reveals that Buddhists with different visions for the modern form of Chinese Buddhism, despite their multifaceted responses, reached a consensus: ascetic practices were part of the tradition worthy of preservation and a strong testament of Buddhist morality. Arguments and eulogies about specific cases, preserved in these periodicals, made Buddhist asceticism an integral part of Chinese Buddhism's modern transformation, which contributes to the rethinking of religion and modernity discourse.
\end{abstract}

Keywords: Buddhist periodicals; Republican-era Buddhism; bodily asceticism; religion and modernity

\section{Introduction}

On 17 July 1933, two monks from Gaoming Temple 高旻寺 intruded into the Right Faith Society 正 信社 ${ }^{1}$ in Wuhan, wishing to cut off their hands as an offering to the Buddha for failing to elicit enough donations for their temple. Members of the society tried to dissuade them from performing self-harm, but to no avail. While the society called for the police, the two monks entered the Skanda Hall and carried out the act. The whole situation was bloody and macabre; thus, an editor of the journal Right Faith, Huici 慧慈, wrote an editorial condemning the backwardness of such an act, which "is against the Dharma, and unbefitting of the modern society"; he further commented "although admirable in spirit, it is totally foolish" (Huici 1933). In an immediate comment, another editor, Huicheng 慧成, echoed the message of Master Taixu 太虛 (1890-1947), who is often credited as the "most influential Buddhist reformist figure" in modern China ${ }^{2}$, regarding monks to be the forerunners of the new age, and criticized the two monks, lamenting that they "live in the twentieth century with minds still in the sixteenth century" (Huicheng 1933). This incident embodies the conundrum that Chinese Buddhism confronted in the early twentieth century: reconciling the tradition's perceived backwardness and the will to modernize. It also points to periodicals as a crucial conduit for the Buddhist community to spread its message.

1 The Right Faith Society is a lay Buddhist organization active in Wuhan, China, from the 1920s to the 1940s, which published a Buddhist periodical named Right Faith between 1932 and 1949. See Hankou fojiaohui chuangshi jixu 漢口佛教會創始記序 [Prologue for the Founding of Hankou Buddhist Society]. Haichao Yin 4: 223 (Taixu 1923); (Welch 1967; Ritzinger 2017a; Xue 2005).

2 (Goossaert and Palmer 2011, p. 80). Extensive scholarships have been written about Taixu, see Welch, The Buddhist Revival in China. Chapter 3 (Welch 1968); (Pittman 2001; Goodell 2012); Ritzinger, Anarchy in the Pure Land (Ritzinger 2017a). 
Growing out of the Indian religious tradition, Buddhist asceticism subsumes various forms of bodily asceticism, from less intense forms of sleep or food deprivation to more extreme forms of mortification of one's flesh (Olson 2015, pp. 4-7). In this article, I focus on the self-mutilation practices recorded by Republican-era Buddhist periodicals to illustrate the mode and motivation of practicing bodily asceticism in the new social and cultural context and how Buddhist asceticism was preserved and debated, through the medium of periodicals, when the religion was undergoing tremendous transformation against the backdrop of modernization.

Asceticism is commonly shared by religions across the world. Émile Durkheim situates asceticism as one of essential elements for religious life (Durkheim 1976, pp. 316-17). Gavin Flood, in his research into the "ascetic self", emphasizes its performance nature and defines asceticism as "the reversal of the flow of the body, which is also an attempt to reverse the flow of time" (Flood 2004, p. 4). In other words, asceticism is closely related to one's embracing of tradition. More specifically for Buddhist traditions, particularly those involving bodily mortification, Reiko Ohnuma examines the "gift-of-the-body" literature in the Indian Buddhist corpus and reveals the dual purpose of "perfection," the training undertaken by the Buddha and imitated by later Buddhists, and "devotion," the Buddhist ritualistic expression of faith. This generosity of body discourse was inherited by and incorporated into Chinese Buddhism through various Mahayana literatures (Ohnuma 2007, pp. 266-67). John Kieschnick's study of monastic asceticism in medieval China demonstrates the importance of making a distinction between Buddhist ascetics and the mundane lifestyle of the monastics (Kieschnick 1997, pp. 16-17). James Benn also observes that many medieval Chinese Buddhists considered self-immolation a valid path for liberation and enlightenment (Benn 2007, p. 8). However, in the modern era, during which a wide range of Chinese traditions has been subject to tremendous criticism, how should we understand cases and polemics recorded in Buddhist periodicals about ascetic practices such as self-immolation, self-mutilation, and blood writing? More importantly, how did Buddhists in the Republican era view these practices? Rebecca Nedostup researches the delimitation of religion from superstition in terms of the state-building in the early twentieth century China, and articulates the state's intention to use charges of "superstition" to subjugate religious organizations (Nedostup 2009, p. 20). Vincent Goossaert and David Palmer have noted the rise of "revolutionary asceticism" in the political realm as the traditionally emphasized moral cultivation was transformed into a moral asceticism following appropriation by both the Nationalist Party and the Communist Party (Goossaert and Palmer 2011, pp. 169-74). However, the religious asceticism did not fade away nor was it substituted with political zeal. Exploring presentations and interpretations of ascetic actions in Buddhist periodicals exemplifies the process of Buddhist tradition being debated, winnowed, preserved, and reshaped during its modernization period.

To approach this issue, I categorize the periodicals in terms of their association with two Buddhist camps: the reform camp and the conservative camp. The former is associated with Taixu and mainly consists of youth monks educated in the new Buddhist seminary, while the latter centers around established figures including Dixian 諦閒 (1858-1932), Yinguang 印光 (1862-1940), and monks closely linked with the Buddhist monastic establishment. This conceptual and rhetorical dichotomy of reform and conservative has taken shape since the 1910s when Taixu explicitly proposed "three revolutions" in the doctrine, institution, and property for the Buddhist community. Taixu's stand on Buddhist reform corresponds to the overall trend of Buddhist modernism, as David McMahan observes, which institutionally emulates the Western monotheistic church, Christianity in particular, and doctrinally embraces rationalism and scientific reasoning (McMahan 2008, pp. 10-11). Basically, whoever opposed Taixu and other reformists were deemed conservatives (Daxing 1929-1930). However, the conservative figures seldom engaged in straightforward arguments with the radical reformists, as Dixian focused on reviving Tiantai Buddhist teaching (Chen 2003), while Yinguang concentrated on promoting the Pure Land Buddhist teachings to the laity (Kiely 2017). These terminologies, nonetheless, are frequently invoked by scholars such as Holmes Welch, who demarcates between "the conservative" and "the reformer", and Don Pittman, who situates Taixu and his reform journey as the central theme for modern 
Chinese Buddhism ${ }^{3}$. Ritzinger recently illustrates the fragility of such a brute dichotomy by showing the devotionalism inside Taixu's thought ${ }^{4}$. Ritzinger, moreover, suggests using "establishment" and "upstart" instead of "reform" and "conservative" for viewing the dichotomous positions within the Republican-era Buddhist community (Ritzinger 2017b). Conceptually, the new terminologies undoubtedly depict the situation in a less ideological manner, with which I agree. However, for this article, I still use the labels "reform" and "conservative", albeit in a cautious way because, first, the reform vis-à-vis the conservative/traditionalist is a popular rhetoric during the process of religious modernization, and Japanese Buddhists had employed similar terms in the second half of the nineteenth century (Shields 2017, chp. 1). Second, I intend to demonstrate the fragility of such oversimplified and problematic rhetoric in the context of modern Chinese Buddhism through the investigation of the bodily asceticism, and further contribute to the invalidation of religious modernity as "the epoch of innovation in distinction from the epochs expressive of tradition and conservation" (Levene 2017). The old terminology serves better to illustrate the conjunction and disjunction between the two camps on asceticism. Periodicals closely associated with the reform camp include Sound of Sea Tide 海潮音, Right Faith 正信, and Modern Sangha現 代 僧 伽, and those tied to the conservative camp are Buddha's Light Society Journal 佛光社社刊, Periodical of the Dharma Propagation Society 弘法社刊, and Spreading the Teaching Monthly 弘化月刊. I also will include relevant cases printed in other Buddhist periodicals.

The appreciation of asceticism in Buddhism in early twentieth-century China was less positive than Weber's recognition of asceticism in Protestantism (Weber 2001). Hu Shih 胡適 (1891-1962), the leading intellectual advocating for strengthening the nation through Westernization in the New Culture Movement, deemed Buddhist ascetics to be religious fanatics. He argues that "China seems to have gone completely mad in one of her strange periods of religious fanaticism" when Buddhist ascetics were venerated for their self-inflictions (Hu 2013, p. 152). This led to Hu Shih's assertion that “Buddhism was opposed to all the best traditions of China” (Hu 2013). Nan Huaijin 南懷瑾 (1918-2012), a Buddhist propagator who received his education in the Republican era, recalls witnessing monks burning off fingers and writing sutras in blood during his youth, and suggests these customs should be viewed as superstition to modern eyes (Nan 2016). As a young intellectual in the early twentieth century, Jin Kemu 金克木 (1912-2000), who later became a translator and Indologist, also criticizes ascetic practices in Chinese Buddhism, believing these actions were transgressions of the original Buddhist doctrine (Jin 2012). Therefore, many Chinese intellectuals, even Buddhist sympathizers, perceived religious asceticism as unbefitting in the modern era.

Moreover, some Buddhist ascetics practicing self-infliction became social spectacles that besmirched the public image of the sangha since the late Qing era. Shen Bao 申報 (Shanghai News) recorded cases of mendicant monks burning off their fingers as a way to elicit donations since the 1870s. In one case, finger-burning was not enough: a monk in Tianjing chopped off one hand to demonstrate his sincerity for raising funds to rebuild a temple (Anonymous 1877). In another report, a beggar monk severely flagellated himself and gained donations from the crowd (Anonymous 1883). The majority of self-infliction spectacles were performed by itinerant monks for donations, resulting in a call to ban and expel these monks on account of their bizarre actions and dubious associations with secret societies (Anonymous 1893). Goossaert meticulously studies cases reported by the Late Qing newspapers and journals regarding clerical ascetic practices, and finds that while certain self-mutilation practices earned some respectability, the overall impression of these beggar-like activities was repulsion (Goossaert 2002). Admittedly, the established monastic community certainly did not welcome mendicant monks, as one of Taixu's reform proposals was to regulate the ordination of monks and to purge the monastic community of corrupted monks without sincere faith in Buddhism (Taixu 1933). Moreover, Yinguang

3 Welch, The Buddhist Revival in China. Chapter 3 (Welch 1968); Pittman, Toward a Modern Chinese Buddhism. Chapter 2 (Pittman 2001).

4 Ritzinger. Parsing Buddhist Modernity in Republican China: Ten Contrasting Terms. Ritzinger. Anarchy in the Pure Land (Ritzinger 2017b). 
attributed the disciplinary decline of the sangha to the proliferation of these unqualified monks. Their view is consistent with the social disparagement of beggar monks dating to the Late Imperial era, as studies by Philip Kuhn and Chün-fang Yü revealed (Kuhn 1990; Yü 1981).

However, despite the disdain of public spectacle of self-inflicted harm by wandering monks, extreme forms of asceticism were still revered and practiced by some Buddhists. In his seminal research on the practice of Chinese Buddhism, Welch lists specialized ascetic practices in order of severity. Burning off fingers and self-immolation are the two most formidable acts in Buddhist asceticism, and many of his informants-who did not witness cases of self-immolation in person-spoke of the acts with great respect (Welch 1967, pp. 321-27). Another case of asceticism was practiced by an eminent monastic figure, Master Jichan, who burned off two of his fingers and carved out a piece of his flesh to set on fire for the Buddha at Asoka Temple in Ningbo (Jichan 1984). Referred to as "the Eight Finger Ascetic", Jichan was greatly respected and was elected as the first president of the Chinese General Buddhist Association in $1912^{5}$. There is no doubt that his devotional act of self-infliction is one of the reasons for his prestige in the Buddhist community.

Therefore, in the early twentieth century, when Chinese society was undergoing a tremendous cultural shift, views on Buddhist asceticism appeared to be multifaceted: secular intellectuals and the non-Buddhist press ridiculed and condemned its madness while the religious community respected it as long as the act was devotional and not self-serving. Thus, I explore reports of self-immolation, incense burning of the body, and blood writing in these Buddhist periodicals to see if the narrative of, perspective on, and attitude toward these practices were affected by the modern cultural shift. In this manner, this article supplements the research of Kieschnick and Benn by demonstrating the continuance and variance of Buddhist bodily asceticism in the modern context, and echoes Ritzinger's call for a new perspective on the tension within the Chinese Buddhist community in the early twentieth century. Moreover, this study also provides perspectives on the "religious question" framework raised by Goossaert and Palmer, which examines the changing mutual adaptation of religion and the modern society ${ }^{6}$, through the case of Buddhist asceticism adapting to the transformed social and political framework of Chinese societies. Furthermore, cases of ritual suicide by Buddhists as a form of protest abound within the contemporary political realm, such as the Struggle Movement in Vietnam in the 1960s (King 2009) and the Tibetan Self-Immolation Protest since 1998 (Whalen-Bridge 2015), and this article would contribute to the understanding of these extremities through an inside perspective of the Buddhist community that immediately predated these instances of political activism.

\section{Accounts of Self-Immolation on Buddhist Periodicals}

Self-immolation is an extreme form of devotional asceticism and a practice that gradually took root once Buddhism entered China. In his study of self-immolation in Chinese Buddhism, James Benn indicates that this form of ritual suicide derives from the mixture of a particular interpretation of Indian texts and the ritual auto-cremation tradition that existed in China long before Buddhism's arrival; he argues that "self-immolation can thus be considered part of the larger process of the Sinification of Buddhism"7. This practice is legitimatized through various Buddhist hagiographical texts, and John Kieschnick has found many cases in biographies of eminent monks, which come from more extensive sources, attesting to widespread veneration for the practice ${ }^{8}$. The major doctrinal source or paradigm of self-immolation depicted in the Buddhist canon is from the Lotus Sutra, in which the Bodhisattva Medicine King (藥王菩薩) burns his body as an offering for the Buddha. The action is interpreted as both "a consequence of attaining the samâdhi [the meditative consciousness]," and a perfection of

\footnotetext{
(Pittman 2001) Pittman. Toward a Modern Chinese Buddhism, p. 50.

(Goossaert and Palmer 2011) Goossaert and Palmer. The Religious Question in Modern China, pp. 2-3.

(Benn 2007) Benn. Burning for the Buddha, p. 11.

(Kieschnick 1997) Kieschnick. The Eminent Monk, p. 50.
} 
vigor, although it also includes a repertoire of meanings for practitioners to pick and choose from ${ }^{9}$. Thus, it is not surprising to see that self-immolation became an act of passive protest over political and social issues in later years.

The first self-immolation case known in Republican China was described in Buddhist Miscellany 佛 學叢報10. On 11 May 1914, a monk named Changhui 常慧 (literary name Langzhao 朗照), dismayed by the moral degeneration of the day and inspired by the Lotus Sutra, sat himself atop a pyre of firewood at the Tianning Temple 天寧寺 in Jiangsu Province and lit the stack, thus "transforming himself at the age of sixty nine" (Di 1914a). Witnesses, moved by his determination, made donations to build a small pagoda on the site of the pyre, inviting Di Chuqing 狄楚青 (1873-1941), editor of Buddhist Miscellany, to write an account of the affair; Di's text in Buddhist Miscellany was accompanied by a printed a portrait of Changhui. In 1923, Changhui's story was collected in New Further Biographies of Eminent Monks 新 續高僧傳 (Yu 1985). James Benn also finds points of continuity between Changhui's biography and "those from hundreds of years earlier"11, suggesting the tenacity of the narrative depicting ascetic actions in early Republican China. Di Chuqing's comment after the biography also suggests a new reception for a lay Buddhist in the modern era, as he wrote "the birth and death, the coming and going of the master are without obstacle and attachment, and this testifies to the efficacy of the Buddhist Dharma. Whether other religions possess similar effects, I do not know" (Di 1914b, p. 495). Here, Di marvels at the devotion, piety, and karmic retribution of Buddhism and perceives them as unique characteristics of Buddhism over other religions, implying Christianity.

The journal Sound of Sea Tide published two accounts of self-immolators in the 1920s. The first, written by the monk Xiegen 解根, is about the self-immolation of a monk named Dizhen 諦真 at the Tiantong Temple 天童寺 in Zhejiang province. As the author writes, the temple invited a prominent monk, Jingquan 靜權, to lecture on The Sutra of Perfect Enlightenment 圓覺經. After hearing the talk, Dizhen told his friend that he had acquired a profound understanding of the Buddhist Dharma and expressed his desire to leave the world. His friend tried to dissuade him by arguing "this world is morally corrupted, and the Dharma is weak while heterodoxy is strong. Correcting people's minds and overcoming the heterodox teachings are our duty. We should make proper efforts to save the world-how can you make this unwise decision"? Dizhen did not answer. One day, however, Dizhen disappeared. After several days passed, he was discovered in a brick kiln with half of his body covered in ashes. Apparently Dizhen had conducted self-immolation without enough firewood for complete incineration. Afterward, the temple cremated his remains. The author admires Dizhen's devotion and pays him respect by recording the affair for posterity (Xiegen 1921). Though the author expresses his admiration for Dizhen's devotion, he nevertheless implies disapproval by quoting Dizhen's friend's exhortation. In addition, the reason for Dizhen's self-sacrifice seems to deviate from many of the hagiographies, as his action resembles ziliao han 自了漢 (one who seeks for his own benefit) ${ }^{12}$.

The second account describes the self-immolation by one Zhigang 智剛 in 1926. Born in Yushan 玉山 prefecture of Jiangxi province, Zhigang was ordained at Mt. Tiantai in Zhejiang province and later pursued studies in Gaoming Temple, Jingshan Temple, and Yunju Temple 雲居寺. He finally settled at Doushuai Temple 兒率寺 near Nanjing. He often lamented people's attachment to their bodies and exhorted them to remember that "the body is like dew within flowers, vines over the well. It changes with the shifting of time. Clinging to the body is futile." In 1926, on 18 March of the lunar calendar, Zhigang prepared a pyre outside the temple and burned himself, vowing to offer his body to the Buddhas of the past, present, and future, and throughout the ten directions of space, for the sake of

\footnotetext{
(Benn 2007) Benn. Burning for the Buddha, p. 60.

10 This is the first Buddhist periodical that appeared in Republican China. For further study on it, see (Scott 2016).

1 (Benn 2007) Benn. Burning for the Buddha, p. 171.

12 The phrase ziliao han came from Chan Master Huangbo Xiyun 黃檗希運, referring to those who only care for themselves. See Zanning 贊寧, ed. Song gaoseng zhuan 宋高僧傳 卷20 [The Biographies of Song Volume 20] (CBETA, T50, no. 2061) 842c7-8. (Zanning 988).
} 
salvation for all sentient beings in samsara. It is suggested that Zhigang conducted self-immolation alone, without an audience, because he left a note in his alms bowl next to the pyre, indicating that he wished to have his ashes scattered with flour to feed wild animals.

The author, Juezhen 覺真, was in awe of Zhigang's noble sacrifice, commenting, “The action and behavior [of Zhigang] should be recorded with these eminent monks". In fact, it was the abbot of Doushuai Temple who requested that Zhigang's biography be written, and the task fell to Juezhen, who completed it with dedication. In the editor's comment, printed at the conclusion of the biography, Manzhi 滿智, a close associate of Taixu, also marveled at Zhigang's cessation of bodily attachment, comparing it with the Medicine King's story in the Lotus Sutra and hoping that the biography would admonish those selfish and venal people of the world (Juezhen 1927). Moreover, Manzhi mentioned that the abbot of Doushuai Temple sent this biography to Buddhist periodicals including Sound of Sea Tide and Journal of the World Buddhist Association 世界佛教居士林林刊, in the hope of preserving Zhigang's story. Compared with the first case of Dizhen, both the author and the editor carried a much more appreciative tone toward Zhigang's self-immolation. Clearly Zhigang's specific wish for the salvation of all sentient beings through his own sacrifice supported the moral salvation argument of many Buddhists of the time.

In 1937, Zhang Chunyi 張純一 (1871-1955) wrote an open letter in Sound of Sea Tide, aiming to dissuade a monk from committing self-immolation. As a lay Buddhist well-versed in Buddhist sutra (Zhang 2006), Zhang learned that the Chan master Xuecan 學參 planned to commit self-sacrifice in the near future and urged Xuecan not to carry out his plan. In the letter, Zhang acknowledged his admiration for Xuecan's devotion and emulation of the Medicine King, but cited the Vimalakirti Sutra and the Diamond Sutra to argue for staying in this world to propagate the Dharma, a choice that would benefit all sentient beings.

Zhang further expounded upon his position, contending that although self-immolation would edify people about the impermanence of the body, it was not a model to be followed by the masses. Second, Zhang argued that the propagation of Buddhism is a difficult calling, and only a truly compassionate individual could bear its tremendous severity and persist to spread the teaching as widely as possible. Then, citing the Lotus Sutra, in which the glow of the Medicine King's self-immolation illuminates "worlds equal in number to the sands of eighty million Ganges" and "burned for twelve hundred years" (Watson 1993), Zhang questioned if Xuechan had mastered a similar kind of shentong 神通, or thaumaturgical ability. Finally, Zhang tempered his tone and suggested that Xuecan might follow the Buddha Sakyamuni's example of being cremated after natural death (Zhang 1937). Persuasions from Zhang and other lay Buddhists may have had some effect on Xuecan, as he originally intended to conduct the act in 1937 but did not go through with it until 1939. Xuecan was recorded in a biography published in Buddhist Semimonthly 佛學半月刊 which included his death verse, in which he expressed pessimistic feelings about the dire situation of Buddhism in the world and viewed his own sacrifice as both paying homage to the Buddha and protesting the rampage of heterodox teachings (Wen 1942).

The conservative camp's periodicals also include an account of self-immolation. In Periodical of the Dharma Propagation Society, a memorial article records the auto-cremation of a Chan master Gaoshi 高 視 on Qingyuan Mountain, Jiangxi Province. The author of the biography, Li Zhengjun 李政鈞, was commissioned by the abbot of Jingju Temple on Qingyuan Mountain. Gaoshi started as a householder in 1909, experiencing the cruelty of butchering livestock, and in 1919 he went through the ordination process on Qingyuan Mountain. Later, he took charge of a small temple near the mountain and practiced strict Buddhist asceticism. He learned about the self-immolation of Master Changhui (the biographer refers to Changhui by his literary name, Langzhao 朗照), whose biography was published in Buddhist Miscellany in 1914, as discussed above. Gaoshi greatly admired Changhui's deed and wished to follow his path.

In the beginning, Gaoshi asked other people to light the fire for him, but those around him refused and tried to talk him out of going through with his plan. After returning to his temple, Gaoshi quietly 
stacked a pyre and set himself on fire. People only discovered what he had done the next day and notified the abbot of Jingju Temple. The abbot and his acolyte came and took Gaoshi's remains back to the Jingju Temple, temporarily leaving them next to a pagoda. During the night, monks in the temple were surprised to see sparkling lights near the pagoda. The abbot decided to build a new pagoda for Gaoshi and commissioned two literati to compile a biography and epitaph for Gaoshi (Li 1930).

There are two noteworthy points of interest here. One is that the inspiration for Gaoshi's action came from the precedent set by Changhui, whose story was communicated through a Buddhist periodical. The biographer does not specify how Gaoshi acquired Changhui's story, but there is no doubt that Di Chuqing's biography was pivotal in spreading the tale. Another point is the miraculous element included in Gaoshi's biography, the implied self-combustion of his remains after being relocated. James Benn notes that in cases of Chinese monks' self-immolation, "as autocremators took on the role of the Medicine King, they also took on his body with all its miraculous powers"13. In addition, Gaoshi's biography also includes explicit reference to the Lotus Sutra. However, the aforementioned self-immolation accounts of Changhui, Dizhen, Zhigang, and Xuecan, although also treating the Medicine King as exemplar, do not involve wondrous elements. One commonality among these biographies is the disapproval of people surrounding these self-immolators. In spite of expressing admiration, none of their immediate acquaintances or close friends supported the ritual suicide.

In Buddha's Light Society Journal, the chief editor Jiang Qian 江謙 (1875-1942) composed a poem to answer a lay Buddhist's question about the case of a monk in medieval China, Muzhen 慕真. Although no letter was printed, a lay Buddhist, Xiaopeng 篗鵬, is supposed to have written to Jiang Qian regarding Muzhen's self-combustion. A Chan master living in the Southern Tang region, Muzhen practiced meditation for forty years. In 1019 during the Northern Song dynasty (960-1279) ${ }^{14}$ when visited by a few lay Buddhists, flames suddenly burst from Muzhen's heart, consuming him entirely and leaving some sarira, or relics, behind ${ }^{15}$. From the title of Jiang Qian's corresponding poem, it seems the question is whether ill will, one of the three poisons in Buddhism, could engender fire in the mind and burn the forest of meritorious karma; in other words, should one understand Muzhen's self-combustion through the fire of samadhi ${ }^{16}$ Jiang Qian's response is that fire is one of the four basic elements in Buddhist cosmology from which all matter is composed, ${ }^{17}$ and fire's function may be either benign or destructive. Due to his diligent spiritual cultivation, suggests Jiang Qian, Muzhen was able to induce the fire of samadhi to destroy his physical form and light up in the realm of infinity (Jiang 1927). Here Jiang Qian's attitude toward this case of self-combustion in the eleventh century is appreciative, treating the incident with awe and attributing its miraculous phenomenon to the monk's profound cultivation.

In general, Buddhist periodicals from both the reform and the conservative camps have printed reports and comments on self-immolation. Because of the extremely ascetic nature and rarity of self-immolations, both the biographers and editors of the journals treated these cases with admiration and respect. In some cases, the self-cremation accounts published in the reform periodicals contain less miraculous accounts and include direct comments opposing this form of sacrifice; yet these variations do not constitute a major difference with those published in periodicals of the conservative camp. However, the willingness of authors who composed these accounts to publish in Buddhist periodicals suggests that this journalistic medium had become a crucial platform for the Buddhist community to memorialize sacred ritual suicides. It also indicates the resilience and tenacity of the bodily asceticism

13 (Benn 2007) Benn. Burning for the Buddha, p. 58.

14 The Southern Tang regime was conquered by the Northern Song regime in 976 AD.

15 (Lan 1985) See Gujin Tushu Jicheng Xuanji Juan 175 古今圖書集成選輯 卷175 [The Selections of Gujin Tushu Jicheng Volume 175]. In Dazangjing bubian 大藏經補編 [Supplement to the Dazangjing], ed. Lan Jifu 藍吉富 (Taipei: Huayu chubanshe, 1985), in Cbeta, B16, no. 88 , p. 473 b21-27.

16 (Hsingyun 2005) The fire Samadhi is considered one of the thaumaturgies. See Fo Guang Shan Buddhist Electronic Texts 佛 光山電子大藏經. Available online: http://etext.fgs.org.tw/ (accessed on 23 August 2018).

17 For a discussion on the Four Great Elements in the modern context, see (Erik 2015). 
discourse in Chinese Buddhism from the medieval period to the modern era, as neither camp mounted any serious challenge toward bodily mortification, at least not directly.

Cases of self-immolation in modern Chinese Buddhism are extremely rare, and there are only two more accounts published in other Buddhist periodicals. In 1925, Voice of Buddha (Foyin 佛音), a journal edited by the Minnan Society of Buddhist New Youth 閩南佛化青年會, which was influenced by Zhang Zongzai 張宗載, the organizer of the Society of Buddhist New Youth in Wuhan (Wang 1999), printed a memorial article for Master Juxing 具行, a disciple of the prominent Chan Master Xuyun 虛 雲 (Campo 2017). Written by a lay Buddhist, Zhang Chuoxian 張拙仙, the article provides a detailed biographical account of Juxing. However, the text does not provide or imply a reason for Juxing's decision to commit ritual suicide. It only records that, before his self-immolation, Juxing sold all his belongings for the purpose of preparing a vegetarian banquet for monks and lay Buddhists. Then, after the completion of his vinaya training held in the temple, Juxing quietly went to the courtyard and committed auto-cremation. Two sections of the account involve some wondrous elements. One is that people found Juxing's body remained in a seated posture while burning, without any movement. While all his clothes, shoes, and other personal artifacts turned to ash, his hand bell 引磬 remained in pristine condition. When falling to the ground, the hand bell made a crisp sound, much louder than ever before. Another interesting aspect is that when Juxing was carrying out the act, both Xuyun and the monks who were wearing clothes woven by Juxing felt a sudden heat around their bodies, suggesting a sympathetic resonance with Juxing's action (Zhang 1925). This story was later collected in Xuyun's chronicle by the compiler, along with the memorial article written by Xuyun (Cen 1995).

The other case is the self-immolation by Master Kezhi 可智 in 1945, the memorial article for which was printed in Bodhisattva (Jueyouqing 覺有情) in 1947. Kezhi was a monk of the Baita Temple 白塔寺 in Linghai prefecture 臨海, Zhejiang province, which was a small temple dedicated to the bodhisattva Guanyin 觀音. Dismayed by the catastrophe brought about by the Second Sino-Japanese War, the master always spoke of committing auto-cremation for the sake of the masses. On 1 April 1945, the birthday of the bodhisattva, Kezhi lit himself on fire, paid homage to the Buddha's statue by circumambulation, and then left the Buddha's Hall to avoid desecration. At the time, troops were stationed in the temple, and one soldier noticed the anomaly and swiftly poured water over Kezhi. The master was dead, yet it seemed that, miraculously, there were no burn scars on his body except for those on his left knee. People around the temple found this difficult to explain, and thus erected a shrine on the spot to memorialize Kezhi (Jian 1947).

These two accounts also involve elements of sympathetic resonance and wondrous phenomena, testifying to the enduring practice of imbuing the voluntary self-destruction of one's body with elements of sanctity and the sublime. Sympathetic resonance, a central notion in Chinese Buddhist cosmology, has long existed within the narrative of self-immolation since the medieval time ${ }^{18}$. This concept operates within the scheme of interdependence by which the supplicant acts to "'affect' the karmic order or to "stimulate' the Buddha" and elicit a response, and thus the wondrous outcome is perceived as a "natural response" (Ho 2017). The self-immolation stories above with wondrous accounts continued to operate within this mentality, as these authors recorded phenomena that would be seen as miraculous by contemporary readers. In addition, all of the self-immolation stories printed in Buddhist periodicals in Republican China, regardless of the journal's affiliation with different camps of Buddhists, include the narrative of the "gift-of-the-body subgenre" summarized by Ohnuma. ${ }^{19}$ This genre was conceived in China with specific reference to the Lotus Sutra, and further developed into Lotus Miracle Tales ${ }^{20}$. Ohnuma defines the "gift-of-the-body" trope as "they must feature the bodhisattva as the hero; they must conceive of the act of bodily sacrifice as a gift; and they must

\footnotetext{
(Benn 2007) Benn, Burning for the Buddha, 6-7.

(Ohnuma 2007) Ohnuma. Head, Eyes, Flesh, and Blood, chapter 1.

(Benn 2007) Benn. Burning for the Buddha, 72.
} 
emphasize the physical body as the item being given away"21. Benn's study finds that devotion to the Lotus Sutra cuts across both monastic and lay Buddhists, as auto-cremators in medieval China could be both monks and laymen ${ }^{22}$. The self-immolation accounts in Republican China clearly carry on this tradition by emphasizing the generosity of self-sacrificers and their wishes for the greater good of the world and the Dharma. Although bodhisattvahood was not emphasized in the narrative, sanctity derived from the sacrifice is certainly suggested. The major difference between the medieval and modern Chinese Buddhists' self-sacrifice stories is that all cases published in Buddhist periodicals exclusively feature monastics, with no laymen involved. Although the veracity of these accounts remains far from certain, stories of self-immolation by monastics published in Buddhist periodicals facilitate the public representations of the monastic community through a moral affirmation. These narratives, disseminated within and outside the Buddhist community, present auto-cremators as either martyrs who chose death for the sake of the people and the world, or devotional practitioners with a genuine pursuit of Buddhist Dharma.

Moreover, both the reform and conservative camp periodicals printed accounts of self-immolation, suggesting that both were comfortable to publicly engage with this extreme form of asceticism, yet their interpretations of the practice were slightly different. Stories printed in Sound of Sea Tide contain fewer miraculous elements, and the journal also printed an open letter arguing against monks taking such action. The conservative camp, on the other hand, expressed approval and respect for the tradition, as shown by Jiang Qian's rationalization of auto-cremation by a monk in medieval China for his readers.

However, self-immolation is only one of the bodily sacrifice practices within Buddhism, and it is both extreme and rare. Incense burning of the body and blood writing are also forms meant to express piety and devotion to one's cause, and they are practiced more commonly in Chinese Buddhism.

\section{Discussing Blood Writing and Bodily Mutilation}

In addition to the incident described in the opening paragraph, there is another case in which a monk initiated a gathering in the lay Buddhist forest 居士林 to copy the Flower Garland Sutra (Avatamsaka Sutra, 華嚴經) with individuals' blood; the editor of Right Faith also reprimanded this gathering along with the hand-cutting incident. The journal reprinted a letter from Yinguang to Hongyi 弘一 (1880-1942) discussing the blood writing and the backwardness of the practice (Yinguang 1933). Although Yinguang's letter was not a total criticism of blood writing-rather, it was directed toward some specific forms of blood writing — the editor certainly meant to use it as a criticism of the monk's initiative at hand.

Therefore, editors of Right Faith tended to reject the bodily mutilation practices prevalent in Chinese Buddhist asceticism, and raised questions about the continuation of such extremity in the modern context. Similar to self-immolation, blood writing, bodily incense burning, and other forms of self-mutilation were parts of a larger tradition of asceticism in Chinese Buddhism. Blood writing, as John Kieschnick's finds, is "a mixture of foreign and indigenous beliefs and traditions" (Kieschnick 2000). Before the arrival of Buddhism, blood writing had been practiced to emphatically express emotions such as sincerity, loyalty, and determination. For example, in Book of the Later Han 後漢書, an official named Yang Xuan 楊琁 (ca. 180 AD) wrote a blood letter on his clothes to protest wrongful treatment at the hands of his superior after he won a battle, through which he successfully defended his reputation ${ }^{23}$.

Both monastics and lay Buddhists across East Asia widely practiced blood writing, and their motivations included acquiring merit-as copying a sutra with one's own blood certainly demonstrates

\footnotetext{
(Ohnuma 2007) Ohnuma. Head, Eyes, Flesh, and Blood, 50.

(Benn 2007) Benn. Burning for the Buddha, pp. 72-77.

23 (Fan) Fan, Ye 范. Zheng Fa Teng Du Feng Yang liezhuan張法滕馮度楊列傳 [List Biographes of Zhang, Fa, Teng, Du, Feng, and Yang]. In Hou han shu 後漢書 [the Book of the Later Han]. Available online: https://ctext.org/hou-han-shu/zhang-fateng-feng-du-yang/zh (accessed on 30 April 2020).
} 
deep sincerity—and the belief that asceticism would improve one's chance of rebirth in the Pure Land while purifying the body ${ }^{24}$.

In the late Ming period, prominent monks such as Hanshan Deqing 呚山德清 (1546-1623) and Ouyi Zhixu 蕅益智旭 (1599-1655) practiced blood writing. Deqing believed that copying sutras with his own blood would generate merit and defend Buddhism from the moral degeneration of the time (Yu 2012, pp. 47-50). For Zhixu, blood writing conveyed several meanings, including the repudiation of Chan Buddhism, which was a heterodox teaching in Zhixu's perspective; the repayment of one's "birth debt" for the purpose of filial piety, as he conducted bloody writing for his mother; and the strengthening of the vinay $a^{25}$. Furthermore, blood writing in Chinese history went beyond the confines of Buddhism, and Confucian literati also engaged in this practice for political purposes, since the practice of making a blood covenant was not uncommon in China prior to the initial spread of Buddhism ${ }^{26}$.

Scriptural sources supporting blood writing in Buddhism can be found in the Brahma's Net Sutra; Flower Garland Sutra; Lotus Sutra; and Perfection of Wisdom literatures, including the Diamond Sutra ${ }^{27}$. Many of these scriptures are more than doctrinal sources, and are also major texts to be copied with blood by Chinese Buddhists. Yet as the incident with the Right Faith society above suggests, some Buddhists in modern China expressed ambivalent views about blood writing and other forms of bodily mutilation. Thus, it is necessary to examine how Buddhist periodicals of the reform and conservative camps presented cases involving blood writing, in addition to bodily incense burning.

Holmes Welch observes that the practice of blood writing was "fairly common in Republican China" 28 , yet he does not delve further, nor does he mention any coverage of the practice by the Buddhist press. In fact, Journal of the Awakening Society 覺社叢書, the predecessor of Sound of Sea Tide, printed a poem by one Yu Jue 余覺 in 1919 praising the copying of the Flower Garland Sutra by the master Shanji 善繼 in the Yuan Dynasty (1279-1368). However, the poem only expresses the author's admiration of blood writing and emphasizes the delusional nature of the body without further reflection on the modern context (Yu 1919). Interestingly, ten years later, Sound of Sea Tide printed another epilogue composed by Wu Yingpei 吳蔭培, a literatus, who toured the place where Shanji's blood writing work was preserved (Wu 1929). Wu's text appreciates Shanji's work as a cultural artifact rather than for its specific Buddhist connotation.

In Sound of Sea Tide, there are more than ten articles regarding the practice, and most are prefaces or epilogues for a blood writing work. In its ninth issue, there appear two epilogues for a blood writing copy of the Lotus Sutra made by the monk Hongmo 宏模. The first preface is by Dahe 大壑, who was actually Renshan, a kindred spirit with Taixu who supported monastic reform, as the signature at the end suggests. Renshan's text first appreciates the Lotus Sutra as an invaluable treasure for Buddhism, and then praises Hongmo's blood writing of the sutra as an achievement, as according to the Lotus Sutra, the Dharma master who produces texts is the most meritorious (Dahe 1922). The second epilogue is written by one Guangong 贯公, whose first sentence states: “When devout Buddhists make grand wishes and conduct marvelous acts like finger burning, seclusion, and copying scriptures with blood, the ignorant would call them superstitious." However, Guangong argued that when the truth is covered by delusion, only Buddhism is capable of recovering the true nature from defilement. Thus, Hongmo's blood writing is meant to save the masses from morally misguided degeneration (Guangong 1922). The author's attempt to fend off accusations of superstition and backwardness concerning blood writing are noteworthy, and his argument also reflects external pressures from the

24 (Kieschnick 2000) Kieschnick, Blood Writing in Chinese Buddhism, 181, pp. 186-190. For case study of blood writing in Japanese Buddhism, see (Fister 2000).

25 (Yu 2012) Yu, Sanctity and Self-Inflicted Violence in Chinese Religions, 1500-1700, pp. 50-55.

26 (Yu 2012) Yu. Sanctity and Self-Inflicted Violence in Chinese Religions, 1500-1700, pp. 57-60; (Kieschnick 2000) Kieschnick. Blood Writing in Chinese Buddhism, pp. 191-193. See also (Lewis 1990, pp. 43-46).

27 (Yu 2012) Yu. Sanctity and Self-Inflicted Violence in Chinese Religions, 1500-1700, p. 41.

28 (Welch 1967) Welch. The Practice of Chinese Buddhism, p. 323. 
secular world regarding this controversial practice. Being labeled "superstitious" was tantamount to losing the legitimacy to exist for any religious groups in modern China, when the boundary between religion and superstition was dictated by state-sponsored modernization ${ }^{29}$.

Then, in 1923, Sound of Sea Tide printed another epilogue written by Xianyin顯蔭 for the blood copying of the Diamond Sutra performed by Dihui 諦慧. Xianyin was a disciple and close acolyte of Dixian, ${ }^{30}$ and in the text he refers to Dihui as his classmate, suggesting Dihui was also a student in the Guanzong Studies Society. The entire text is conventional in terms of its stylistic commendation of the author and the sutra itself. Overall, Xianyin interpreted Dihui's blood writing as a devotional act for the Dharma (Xianyin 1923).

Besides reasons of devotion for the Buddhist Dharma and merit-accumulation, however, Buddhists also practiced blood writing due to filial piety to one's parents, though oftentimes these motivations were mixed. The journal printed two articles in 1923 about a lay Buddhist, Xia Qixuan 夏琦玷, who copied Buddhist sutras and drew paintings of the Buddha with the blood of her sister and herself. The first article is a prayer text written by Xia, while the second is an explanatory article by Xia's friend, who marvels at the act and recounts the reason behind it (Xia 1923; Huyang 1923). The exact sutra they copied is not specified, yet the reason for blood writing is clearly stated to be a response to their father's deteriorating health. Therefore, the purpose of the act is purely filial piety, as Xia resorted to the power of Buddhism to assist her father's recovery. It should be noted that it is rather common to observe the motivation of filial piety for blood writing activities, even for monastics, since Buddhism in China had long embraced the Confucian ethic of repaying the kindness that parents show to their children (Teiser 1988, chp. 4).

One year later, a monk named Daoshen 道申 wrote a votive text for copying the Lotus Sutra with his own blood and published it in Sound of Sea Tide. Daoshen explains his reason for blood writing: "I thought, since taking convenience of the non-beginning [無始] and reincarnating through the six realms, I was fortunate to be born in China and join the sangha. It was for the blessing of the Dharma. Thus, I vowed to copy the sutra with blood from my tongue." Then, Daoshen made four vows upon the completion of the blood writing, which took three years to complete. The first was his hope that his action would counteract all the negative karma accumulated in his previous lives; the second was for his parents and teachers, that they would enjoy longevity and be reborn in the Pure Land; the third was for the masses to be enlightened by Buddhism and liberated from samsara; the last is the wish for himself to be able to attain rebirth in the Pure Land (Shi 1924). It is clear for Daoshen, the motivation and purpose for conducting this ascetic practice were to acquire merit for himself, his close relatives and teachers, and the masses. Though not strongly emphasized, filial piety was included within his grand wishes. There is one additional report of blood writing that appears in Sound of Sea Tide in the 1940s, but this only provides limited information about a monk named Xiangrui 祥瑞 who copied sutra and painted with his blood (Anonymous 1943).

Therefore, it is clear that Sound of Sea Tide, a periodical managed by the reform-minded Buddhists, did not shy away from printing texts concerning the practice of blood writing. In fact, Taixu himself also practiced blood writing, yet in a wholly different context. In 1933, the journal Modern Buddhism, the successor of the aggressive Modern Sangha, reprinted news from Reuters' Shanghai station that Taixu wrote a petition to the Mongolian and Tibetan Affairs Commission 蒙藏委員會 for a swift resolution to the borderland dispute in the Kham area between the Sichuan warlord and the Tibetan regime in Lhasa $^{31}$. The noteworthy part is the detail that Taixu cut his finger and wrote the petition with his blood (Anonymous 1933). Hence, the blood writing Taixu practiced was devoid of the traditional merit-seeking purpose, since no sutra was copied, and the blood petition was more in line with the

\footnotetext{
(Nedostup 2009) Nedostup, Superstitious Regimes, pp. 10-16.

(Fang 2006) Fang Zuyou, Tiantaizong Guanzongjiangsi sizhi, pp. 90-93.

For details about the Sino-Tibetan Conflict in Kham, see (Goldstein 1991, pp. 221-24).
} 
instrumentality of blood to demonstrate loyalty, sincerity, determination, and in this case, urgency, as in the Chinese political tradition ${ }^{32}$. In addition, Zhifeng, a discipline of Taixu, expressed his admiration toward the blood writing of the Lotus Sutra by a monk Puqin 普欽, who was also a student in the Minnan Buddhist Seminary, by composing and publishing an epilogue in Sichuan Buddhism Monthly 四川佛教月刊. In Zhifeng's text, he mentioned that Puqin, after visiting a site where the Buddha's sarira was displayed, committed to copying the sutra with his tongue blood, and upon completion, Puqin also burned his finger for the Buddha's sarira and the Lotus Sutra. Zhifeng, while conveying his appreciation for Puqin's act, also professed remorse for his own lack of dedicated practice and only uttering empty words (Zhifeng 1933). Thus, at least for Taixu and many of his disciples, blood writing was not a tradition unfit for their reform agenda.

Buddhist periodicals in the conservative camp also published texts regarding blood writing, but there are fewer cases recorded compared with Sound of Sea Tide and other periodicals in the reform camp. In Periodical of the Dharma Propagation Society, I found only one article, published in 1935, on the blood-writing practice. It is an epilogue written by one Zhongjing 鐘鏡 for the copying of the Diamond Sutra in blood by a monk named Chengxin 誠信. Chengxin was a disciple of Master Baojing, the successor of Dixian for the abbotship in the Guanzong Temple and the chief editor of its periodical. Filial piety was the main reason for Chengxin's decision to conduct blood writing, yet the case is peculiar because Chengxin's father also left the family to join the sangha; hence, Chengxin copied the sutra with his blood and sent it to his father in Sichuan province. Chengxin wished that the merit accumulated from blood writing would benefit his father's practice of Buddhism (Zhongjing 1935).

In Spreading the Teaching Monthly, three texts appeared in 1947 that acclaim the blood writing of the Flower Garland Sutra by a lay Buddhist, Fu Jinqiu 傅近秋. Fu was a devout lay Buddhist, medical doctor, and follower of Yinguang (Yingche 1942). He copied the entire Flower Garland Sutra with his blood in 1944, as one of the epilogues suggested (Shou 1947). Three monks provided texts treating Fu's endeavor: Cizhou 慈舟 (1877-1958), Yuanying, and Shoupei 守陪 (1884-1955). Yuanying was a well-respected figure among the Buddhist establishment whose acquaintances included Taixu and some reform-minded monks. Both Cizhou and Shoupei were old-fashion scholarly monks, as the former dedicated himself to studying the Flower Garland Sutra and the vinaya (Yu 1995, pp. 63-65), while the latter ventured into the study of Awakening of Faith in the Mahayana Buddhism and Yogācāra philosophy ${ }^{33}$. All three praise Fu's effort, and Shoupei in particular expresses admiration for both Fu's devotion and his calligraphy, which was strong in stroke and clear in shape (Yuanying 1947; Cizhou 1947). Yuanying also connects Fu's blood writing with the Dharma gathering 法會 he organized, at which Yuanying distributed thousands of copies of the Flower Garland Sutra. Yuanying believed that in addition to social philanthropy's provision of materials to the needy, the distribution of the sutra would fundamentally save the masses, and Fu's blood writing certainly contributed to the accumulation of merit for this cause.

Overall, articles about blood writing from the conservative camp's periodicals appear to be more limited in volume as well as in scope. Yet we cannot conclude that the conservative camp refrained from reporting this practice. Rather, given that few of the camp's periodicals could match the circulation of Sound of Sea Tide, there is no doubt that authors would wish to write and propagate the act on a more prominent and widely accessible platform. Furthermore, in addition to the Buddhist periodicals of primary research noted here, texts and reports on blood writing activities by both monastics and householders also appear in journals such as Bodhisattva, Journal of the World Buddhist Association, and Buddhist Semimonthly, all of which were influential among the lay Buddhist community.

32 (Yu 2012) Yu. Sanctity and Self-Inflicted Violence in Chinese Religions, 1500-1700, pp. 60-61.

33 (Yinshun 1973) Yinshun. Daonian Shoupei shangren 悼念守培上人 [Memorial for Master Shoupei]. In Huayu xiangyunh 華 雨香雲. CBETA, Y23, no. 23, p. 349a1. 


\section{The Dissenting Voice}

Based upon the frequent appearance of articles on blood writing and other acts of bodily mutilation in Buddhist periodicals, however, it cannot be simply asserted that bodily asceticism was accepted and espoused by the Buddhist community as a whole, including both the reform and conservative camps. Dissenting voices have existed since the medieval period. Yijing 義淨 (635-713), the Buddhist translator and a vinaya master who made a pilgrimage to India, criticized self-immolation by Chinese monks and contended that abandoning one's body is a waste of opportunity since humanity has a better chance to attain Enlightenment ${ }^{34}$. Moreover, Yijing questioned the legitimacy of such practices from the vinaya perspective (Kleine 2006). Kieschnick also notes that a monk named Jiaoran 交然 in the Tang dynasty made the argument that "writing a holy scripture in one's blood is wrong because the body is a vile, unclean thing" 35 . In Republican China, opinions partially or totally disavowing bodily mutilation practices also existed among the Buddhist community.

Interestingly, Yinguang was one of the prominent monks who expressed ambivalence about blood writing and incense burning of the body. In 1921, one of his letters to Ding Fubao 丁福保 (1874-1952), regarding bodily incense burning, was published in Buddhist Studies Monthly (Foxue yuekan 佛學月 刊) (Scott 2015; Andrews 2014, pp. 122-33). In the letter, Yinguang cited Ouyi Zhixu's act of burning incense on his arms to argue that the practice belonged to dana, the act of cultivating generosity by severing the attachment to one's body. However, Yinguang further commented: "If one only admires the appearances of the act and aims to acquire prestige by following the example [of bodily incense burning], then it is an ascetic practice in vain, even if one burns his entire body" (Yinguang 1921). Thus, Yinguang sets the criterion of assessing ascetic practices by motivation, and if one commits such an act only to create a spectacle instead of out of the profound understanding of Buddhist teachings, then the practice yields no merit or efficacy.

Then, in a letter to Hongyi on blood writing, Yinguang also tried to dissuade Hongyi from performing the act. First, Yinguang argued that blood writing is not suitable for new learners of Buddhism, as it would weaken the practitioner's spirit and slow their cultivation. Then, Yinguang reiterated the principle of blood writing, which should be motivated by sincerity and respect toward the Dharma and sutra, echoing his response to Ding. In the end, Yinguang criticized some of the recent practitioners of blood writing directly, stating that they "produced negative karma" because some drew too much blood in the beginning without properly blending it with gold or other metal chippings for better preservation, resulting in the strong smell of the blood-writing work. In addition, Yinguang also lamented that some blood writers copied the sutra as if they were practicing calligraphy and rendered the text illegible ${ }^{36}$. In terms of epitomes, Yinguang regarded Hanshan Deqing, Master Miaofeng 妙峰 (1539-1612), and Ouyi Zhixu as paragons of blood writing, all of whom are known for their profound learning of the Dharma. Moreover, both Deqing and Miaofeng received support from the royal family when engaging in copying sutras with their blood, thus enabling their blood text to be well preserved. Zhixu, according to Yinguang, would bow three times, circumambulate the Buddha's statue three times, and recite the Buddha's name twelve times before writing one character with his blood $^{37}$. Therefore, Yinguang set the criterion for proper blood writing and bodily mutilation rather high, implicitly dissuading people in the modern period to follow.

Yinguang's opposition to bodily mutilation is implicit, but one author, Changbiao 長颭, wrote an article in 1937 explicitly calling for cessation of the practice. In "Liberated from Incense Burning," printed in Light of the Human World 人海燈, the author cast doubt on incense burning, whether of the head, chest, finger, or whole body, calling it an act of cruelty and a "self-injured trick 苦肉計."

\footnotetext{
(Benn 2007) Benn. Burning for the Buddha, pp. 115-16.

(Kieschnick 2000) Kieschnick. Blood Writing in Chinese Buddhism, p. 190.

(Yinguang 1933) Yinguang. Wei cixue xiejing fu Hongyi Lüshi shu. pp. 249-51.

(Yinguang 1933) Yinguang. Wei cixue xiejing fu Hongyi Lüshi shu, p. 250.
} 
Changbiao dismissed the appreciation of bodily burning for the Buddha because he opined that the compassionate Buddha would not accept such a ghastly offering. Even if there is textual support from different sutras, Changbiao argued that bodhisattvas who performed self-immolation were advanced in their cultivation so that they were able to conduct the act with ease and without pain. Changbiao went on to cite an example of a Buddhist nun in Ningbo, Dican 諦參, who burned her head, chest, and fingers for the Buddha, resulting in the spread of her reputation. The asceticism of Dican led to the proselytization of many lay followers under her guidance, and some monastics in nearby regions also wished to take advantage of her reputation by joining her lineage. Then Dican asked these monastics to practice bodily mutilation. Changbiao recounted that one of the monastics, after burning his head and chest, could not endure the pain of burning off his fingers and was disavowed by Dican. From this case, Changbiao bemoaned the rampancy of belief in bodily asceticism in Chinese Buddhism, and called for ending the incense-burning practice.

Changbiao also quoted Yijing's argument against self-immolation and the writings of a monk Wanshi 頑石, who studied in Sri Lanka and found no textual support for the burning of incense scars into the head in the Pali Buddhist canon, to argue for the illegitimacy of Chinese Buddhists' incense burning. Ultimately, Changbiao contended that Buddhism encourages the free development of individuals. Although disciplinary regulation exists for practitioners, it should follow rational rules instead of a barbaric form of asceticism. In general, Changbiao deems severe bodily mutilation unsuitable for modern times (Changbiao 1937). Moreover, it should be noted that Sea Light of Human World was founded by Jicheng 寄塵 and Tongyi 通一 and later managed by Zhifeng, all of whom were reform-minded monks and close associates of Taixu (Huang 2011). Thus, there are voices from both the reform and conservative camps' periodicals opposing the practice of bodily mutilation in periodicals.

In general, the voices opposing bodily asceticism were weaker than those expressing admiration in the Buddhist press. There may be several reasons for this. First, asceticism has constituted an inalienable part of the Chinese Buddhist tradition, particularly in hagiographical narratives. As Kieschnick, Benn, McGuire (McGuire 2014), Yu, and many other scholars show, ascetic practice became an ingrained custom for Buddhists in China to express their devotion, determination, filial piety, and other votive declarations, and different forms of bodily asceticism, varying in degree of intensity, constituted a repertoire from which the practitioners could choose. Although the conception of the body and health underwent drastic changes in modern China (Bu 2017), its repercussions did not reach the less perceptible area of bodily ascetic tradition in Buddhism, at least not in the early twentieth century and without external pressure from the state.

The second reason may be the infrequency of severe self-mutilation practiced in Republican China. As cases of auto-cremation show, ritual suicides committed by Buddhists, primarily monastics, were rare. The less mortal forms of bodily mutilation, such as chopping off one's hand or incense burning parts of the body, were practiced by some, yet the Buddhist community did not explicitly advocate such actions, hence resulting in relatively fewer cases. The news coverage by the secular press on incidents of monks committing self-mutilation generally do not consider them as part of the established Buddhist community, but rather as mendicant monks who were also disdained by the Buddhist establishment. Blood writing was the most frequent form of bodily asceticism in Republican China, yet its meaning transcended Buddhism and became a popular practice to emphasize one's determination and dedication, since many revolutionaries and social activists in the late Qing and Republican eras also resorted to blood writing ${ }^{38}$. Hence, blood writing by Buddhists was not repulsive for the secular masses and Buddhist periodicals did not shy away from reporting it.

The third reason relates to the perceived decline of monastic Buddhism in early twentieth-century China. Bodily asceticism, regardless of motivation, tends to morally sanctify the practitioner,

38 For example, a Chinese student in Paris broke his finger and wrote the blood slogan protesting the Versailles Treaty in 1919. See (Anonymous 1928). 
demonstrating their resolution to abandon material and physical enjoyment for spiritual pursuits. Bodily mutilation practices defied and counteracted the corruption image of Chinese Buddhism, so that the majority of reports in Buddhist periodicals concentrated on the religious and moral pursuit of the practitioner. Although some reports from the reform camp's periodicals might demonstrate concern for the accusation of backwardness and superstition, Buddhists at the time generally considered bodily asceticism as an accepted tradition.

\section{Concluding Remarks}

This article, with its analysis of published accounts of Buddhist asceticism, adds to the nuanced view regarding the categorization of "reform" and "conservative" among Chinese Buddhists in the early twentieth century. Taixu and his followers were not fundamentally different from those in the "conservative camp" in terms of writing and publishing ascetic stories. In fact, periodicals under Taixu's influence printed more reports on this matter. Both camps regarded these ascetic practices as exemplifying the genuine piety and compassion of Buddhists, which should be venerated and eulogized. From that vantage point, the spreading of ascetic stories was conducive to the cohesion of the Buddhist community in a tumultuous era. Even though dissenting voices on asceticism did exist, they concentrated on the effect of actions rather than the motive.

In early twentieth-century China, asceticism was perceived with ambivalent connotations. As Goossaert and Palmer's study indicates, it could be appropriated by the political force; or it could be treated as foolishness and unbefitting the modern society, as in the writings of intellectuals like Hu Shih. However, despite these developments, Buddhist periodicals continued to praise bodily asceticism. Although the so-called "Buddhism decay" has been labeled as a "historiographical conceit" 39 , this crisis of consciousness was nevertheless embedded in the agendas of different groups of Buddhists in early twentieth-century China. Therefore, practices of self-immolation, bodily mutilation, and blood writing were recorded and eulogized through the platform of Buddhist periodicals, rendering bodily asceticism, especially cases of auto-cremators, visible to the wider public. It is noteworthy that the majority of these ascetic practices were not intended for public display, unlike the later political protests via self-harm carried out by the Vietnamese and Tibetan Buddhists. Thus, without Buddhist periodicals, these stories risk falling into oblivion.

The preservation of Buddhist asceticism by periodical literatures in modern China adds to the rethinking of the troublesome dualism of religion and modernity. Gavin Flood summarizes the trajectory of how modernity erodes the religious "ascetic self" and relegates the latter into "a minority pursuit." And Flood sees the legitimacy of the ascetic self could only be attained through a postmodern critique of modernity ${ }^{40}$. This conceptualization of religion and modernity, despite its popularity, has been challenged by recent studies. For instance, a study by Jason Josephson-Storm contends for the "myth of disenchantment" from its Western intellectual origin, and finds that the "disenchanted world" anticipated by the major theorists of modernity is nowhere to be found in the contemporary world (Josephson-Storm 2017). More broadly, Shmuel Eisenstadt situates the Western modernity as a "basic reference point" and stresses the development of "multiple modernities" in other regions of world (Eisenstadt 2000). The findings in this article shed light on how the religion and modernity dualism was questionable from its early phase in China. The continuance of Chinese Buddhist asceticism in the early twentieth century in the context of the state and the society undergoing rapid modernization, and its public presentation by periodicals, suggest that for the religious community the modernity discourse could not dominate their specific practices, nor could it excise religious practitioners from their traditions. Though reconfiguration of the religion did take place, such as in the new distinction between religion and superstition in cases discussed here, the moods and motivations for practicing

39 (Goossaert 2002) Goossaert. Starved of Resources: Clerical Hunger and Enclosures in Nineteenth-Century China. p. 110.

40 (Flood 2004) Flood. The Ascetic Self, pp. 235-36. 
bodily asceticism retain a significant part of its tradition, represented by religious devotion, filial piety as a virtue, and the Buddhist compassion.

The form of devotion-driven asceticism continues to this day in Mainland China, as illustrated by the report of the Dabei Temple 大悲寺 (Anonymous 2013) where certain monks have burned off their fingers as an act of devotion. Blood writing has also been practiced by lay Buddhists in contemporary China; for example, a famous Chinese pop singer was reported to have transcribed a sutra with her blood ${ }^{41}$. Through the preservation and continuation of the ascetic tradition, Chinese Buddhism has forged a modernity discourse with its own characteristics, which carries a hybridity of modern rationality and the devotional commitment toward Buddhist religiosity. This hybrid modernity results in the vitality and continuity of Buddhism embedding within the Chinese cultural realm, contributing to the revitalization of Buddhism in the post-Mao era.

Funding: This research received no external funding.

Conflicts of Interest: The author declares no conflict of interest.

\section{Abbreviations}

$\begin{array}{ll} & \text { Huang Xianian 黃夏年, ed. 2006. Minguo Fojiao qikan wenxian jicheng 民國佛教期刊文 獻集成 } \\ \text { MFQ } & \text { [Complete Collection of Republican-Era Buddhist Periodical Literature]. Beijing: Quanguo } \\ & \text { tushuguan, vol. 209. } \\ & \text { Huang Xianian ed. 2008. Minguo Fojiao qikan wenxian jicheng bubian } \\ \text { EFQB } & \text { 民國佛教期刊文獻集成補編 [Supplement to the Complete Collection of Republican-Era Buddhist } \\ & \text { Periodical Literature]. Beijing: Zhongguo shudian, vol. 83. } \\ & \text { Taisho Shinshu Daizokyo 大正新修大藏經 (Taisho Tripitika). Tokyo: Taisho Issaikyo Kankokai, vol. } \\ & \text { 100,1924-1934. Accessed from the online archive of the Chinese Buddhist Electronic Text } \\ \text { T } & \text { Association (CBETA) <http://www.cbeta.org>. }\end{array}$

\section{References}

Andrews, Bridie. 2014. The Making of Modern Chinese Medicine, 1850-1960. Vancouver: University of British Columbia Press.

Anonymous. 1877. Kuxing toubuo 苦行頭陀 [The Ascetic Monk]. Shen Bao, August 3.

Anonymous. 1883. Bushi xinfa 佈施新法 [New Method for Donation]. Shen Bao 申報, June 30.

Anonymous. 1893. Quzhu youseng yi 驅逐游僧議 [On the Proposal to Dispel Wandering Monks]. Shen Bao, April 10.

Anonymous. 1928. Japan's War in China. The Chinese Students' Monthly 23: 7.

Anonymous. 1933. Fojiao yaowen 佛教要聞 [Important News of Buddhism]. Xiandai Fojiao 68: 555.

Anonymous. 1943. Yiyue fojiao 一月佛教 [Buddhism in January]. Haichao Yin 201: 324.

Anonymous. 2013. 大悲寺主持證實「燃指供佛」修行: 和自殘是兩個概念 (The Abbot of Dabei Temple Confirms the Practice of Burning Finger for the Buddha: 'It is different from self-injury'). Renwu zazhi 人物雜誌. September 13. Available online: http://news.ifeng.com/shendu/renwu/detail_2013_09/13/29568927_0.shtml (accessed on 2 May 2020).

Benn, James. 2007. Burning for the Buddha: Self-immolation in Chinese Buddhism. Honolulu: University of Hawai'i Press.

Bu, Liping. 2017. Public Health and the Modernization of China, 1865-2015. New York: Routledge.

Campo, Daniela. 2017. Chan Master Xuyun: The Embodiment of Ideal, the Transmission of a Model. In Making Saints in Modern China. Edited by David Ownsby, Vincent Goossaert and Ji Zhe. New York: Oxford University Press, pp. 99-136.

41 2013. 王菲中秋手抄血佛送友人:不出家 (Wangfei Copies Sutra with her Blood as Mid-Autumn Festival Gift: I Will Not join the Sangha). Changchun Wanbao 长春晚报, September 23. Available online: https://fo.ifeng.com/news/detail_2013_09/23/ 29809030_0.shtml (accssed on 6 July 2020). 
Cen, Xuelv 岑學呂, ed. 1995. Xuyun fashi nianpu 虛雲法師年譜 (The Chronicle of Master Xuyun). Beijing: Zongjiao wenhua chubanshe.

Changbiao 長颷. 1937. Cong ranxiang zhong jiefang chulai 從燃香中解放出來 [Liberated from Incense Burning]. Renhai Deng 70: 497-98.

Chen, Yongge 陳永革. 2003. Fojiao Honghua de Xiandai Zhuanxin: Minguo Zhejiang Fojiao Yanjiu 1912-1949 佛教弘化的現代轉型: 民國浙江佛教研究 1912-1949 [The Monden Transformation of Buddhism Promulgation: Study of Zhejiang Buddhism in Republican China 1912-1949. Beijing: Zongjiao wenhua chubanshe.

Cizhou 慈舟. 1947. Da fangguangfo huayanjing xu 大方廣佛華嚴經敘 [Epilogue to the Flower Garland Sutra]. Honghua Yuekan 70: 137-38.

Dahe 大壑. 1922. Ba Hongmo heshi xueshu miaofa lianhua jing 咙宏模和尚血書妙法蓮華經 [Epilogue for Hongmo's Blood Writing of the Lotus Sutra]. Haichao Yin 151: 450-51.

Daxing 大醒. 1929-1930. Zhongguo fojiao jianghua: Zhongguo fojiao xinjiu liangpai zhi qushi 中國佛教講話: 中國 佛教新舊兩派之趨勢 [Talks on Chinese Buddhism: Trends of the New and the Old Factions within Chinese Buddhism]. Xiandai Sengqie 2: 361-63.

Di, Chuqing 狄楚青. 1914a. Fenqu gongfo 焚供佛 [Burning the Body for Buddha]. Foxue Congbao 4: 495.

Di, Chuqing 狄楚青. 1914b. Langzhao fashi wei fenshen qian wushiyu sui zhishi xiaoxiang 朗照法師未焚身前五 十餘歲之時肖像 [Picture of Master Langzhao in his Fifties before Self-immolation]. Foxue Congbao 4: 351.

Durkheim, Émile. 1976. The Elementary Forms of the Religious Life. Translated by Joseph Ward Swain. London: George Allen \& Unwin Ltd.

Eisenstadt, Shmuel. 2000. Multiple Modernities. Daedalus 129: 1-29.

Erik, Hammerstrom. 2015. The Science of Chinese Buddhism: Early Twentieth-Century Engagements. New York: Columbia University Press, pp. 66-67.

Fan, Ye 范晔. 445. Hou Hanshu 后汉书 (The Book of the Later Han). Chinese Text Project. Available online: https://ctext.org/hou-han-shu/ens (accessed on 30 April 2020).

Fang, Zuyou 方祖猷. 2006. Tiantaizong Guanzongjiangsi sizhi 天台宗宗寺志 1912-1949 [Gazetteer of Guanzong Lecture Temple of Tiantai Buddhism]. Beijing: Zongjiao wenhua chubanshe.

Fister, Patricia. 2000. Creating Devotional Art with Body Fragments: The Buddhist Nun Bunchi and Her Father, Emperor Gomizuno-o. Japanese Journal of Religious Studies 27: 213-38. [CrossRef]

Flood, Gavin. 2004. The Ascetic Self: Subjectivity, Memory and Tradition. Cambridge: Cambridge University Press.

Goldstein, Melvyn C. 1991. A History of Modern Tibet, 1913-1951: The Demise of the Lamaist State. Berkeley: University of California Press.

Goodell, Eric. 2012. Taixu's (1890-1947) Creation of Humanistic Buddhism. Ph.D. thesis, University of Virginia, Charlottesville, VA, USA.

Goossaert, Vincent. 2002. Starved of resources: Clerical hunger and enclosures in nineteenth-century China. Harvard Journal of Asiatic Studies 62: 77-133. [CrossRef]

Goossaert, Vincent, and David A. Palmer. 2011. The Religious Question in Modern China. Chicago: University of Chicago Press.

Guangong. 1922. Ba Hongmo heshang xueshu fahua jing 跋宏模和尚血書法華經 [Epilogue for Hongmo's Blood Writing of the Lotus Sutra]. Haichao Yin 151: 451.

Ho, Chiew Hui. 2017. Sinitic Buddhist narratives of wonders: Are there miracles in Buddhism? Philosophy East and West 67: 1118-42. [CrossRef]

Hsingyun. 2005. Fo Guang Shan Buddhist Electronic Texts 佛光山電子大藏經. Available online: http://etext.fgs. org.tw/ (accessed on 23 August 2018).

Hu, Shih. 2013. English Writings of Hu Shih Chinese Philosophy and Intellectual History. Edited by ChihP'ing Chou. New York: Springer.

Huang, Xianian. 2011. Renhai Deng Chongyin Qianyan 人海燈重印前言 [Preface for the Reprint of Sea Light of Human World]. Fojiao Tushuguan Guankan 佛教圖書館館刊. Available online: http://www.gaya.org.tw/ journal/m52/52-book2.pdf (accessed on 25 July 2020).

Huicheng 慧成. 1933. Shishi jiaowo shuo liangjuhua 事實叫我説兩句話 [My Comment for the Incident]. Zhengxin 43: 249.

Huici 慧慈. 1933. Wei Gaoming Si heshang huayuan bude zai benhui duanshou shi gaozheng zhengxin huiyuan 為 高旻寺和尚化緣不得在本會斷手事告正信會員 [To Members of the Right Faith Society for Monks of Gaoming Temple Cutting off Their Hands after Failing to Solicit Donation]. Zhengxin 43: 248-49. 
Huyang, Peiling 胡湯佩琳. 1923. Zhongying laobo danchen qinv wuyou Derong Detong cixue shujing huixiang wei shou yin sui xi yan 仲膺老伯誕辰其女吾友德融德通刺血書經繪像為壽因隨喜焉 [Praising Derong Detong, Daughters of Zhongying, Writing Sutra and Making Painting with Their Blood on Zhongying's Birthday]. Haichao yin 156: 115.

Jian, Ming 剑鸣. 1947. Linghai Kezhi dashi zifen zuiji 臨海可智大師自焚追記 [Memorial of the Self-immolation by Master Kezhi in Linghai]. Jueyou Qing 89: 301.

Jiang, Qian 江謙. 1927. Da Xiaopeng jushi wenyi chen shi xinzhong huo neng shao gongdelin heyi Nantang Muzhen chanshi lingshan zuohua shi yi sanmeihuo zifen qishen 答䈗鵬居士問疑瞋是心中火能燒功德 林何以南唐慕真禪師靈山坐化時以三昧火自焚其身 [Reply to Householder Xiaopeng on if Ill Will Could Engender Fire in the Mind and Burn the Forest of Meritorious Karma, then How to Understand Muzhen's Self-combustion through the Fire of Samadhi]. Foguangshe Shekan 16: 263.

Jichan 寄禪. 1984. Bazhi Tuotou Shiwen ji 八指陀文集 (Poems Collection of the Eight Finger Ascetic). Changsha: Yuelu shushe.

Jin, Kemu 金克木. 2012. Rensheng yu Xuewen 人生与问 (Life and Scholarship). Beijing: Beijing lianhe chuban gongsi. Josephson-Storm, Jason. 2017. The Myth of Disenchantment: Magic, Modernity, and the Birth of the Human Sciences. Chicago: University of Chicago Press.

Juezhen 覺真. 1927. Zhigang chanshi ranshen gongfo jia 智剛燃身供佛记 [Account of Master Zhigang's Self-immolation for Buddhas]. Haichao Yin 168: 186-87.

Kiely, Jan. 2017. The Charismatic Monk and the Chanting Masses-Master Yinguang and His Pure Land Revival Movement. In Making Saints in Modern China. Edited by David Ownsby, Vincent Goossaert and Ji Zhe. New York: Oxford University Press.

Kieschnick, John. 1997. The Eminent Monk: Buddhist Ideals in Medieval Chinese Hagiography. Honolulu: University of Hawai'i Press.

Kieschnick, John. 2000. Blood Writing in Chinese Buddhism. Journal of the International Association of Buddhist Studies 23: 177-94.

King, Sallie B. 2009. Socially Engaged Buddhism. Honolulu: University of Hawai'i Press.

Kleine, Christoph. 2006. The Epitome of the Ascetic Life': The Controversy over Self-Mortification and Ritual Suicide as Ascetic Practices in East Asian Buddhism. In Asceticism and Its Critics: Historical Accounts and Comparative Perspectives. Edited by Oliver Freiberger. Oxford: Oxford University Press, pp. 153-77.

Kuhn, Philip A. 1990. Soulstealers: The Chinese Sorcery Scare of 1768. Cambridge: Harvard University Press.

Lan, Jifu. 1985. Gujin Tushu Jicheng Xuanji Juan 175 古今圖書集成選輯 (The Selections of Gujin Tushu Jicheng). In Dazangjing bubian 大藏經補編 (Supplement to the Dazangjing). Edited by 藍吉富. Taipei: Huayu chubanshe, Available online: http://cbetaonline.cn/zh/B0088_055 (accessed on 30 July 2020).

Levene, Nancy. 2017. Powers of Distinction: On Religion and Modernity. Chicago: The University of Chicago Press. Lewis, Mark Edward. 1990. Sanctioned Violence in Early China. Albany: State University of New York Press.

Li, Zhengjun 李政鈞. 1930. Jiangxi Qingyuanshan Gaoshi chanshi fenshenji 江西青原山高焚身 [The Account of Self-immolation of Master Gaoshi in Qingyuan Mountian, Jiangxi]. Hongfa Shekan 37: 191-92.

McGuire, Beverly F. 2014. Living Karma: The Religious Practices of Ouyi Zhixu. New York: Columbia University Press.

McMahan, David. 2008. The Making of Buddhist Modernism. New York: Oxford University Press.

Nan, Huaijin 南怀瑾. 2016. Ruhe Xiuzheng Fofa 如何修佛法 (How to Cultivate and Practice Buddhist Dharma). Shanghai: Fudan daxue chubanshe.

Nedostup, Rebecca. 2009. Superstitious Regimes: Religion and the Politics of Chinese Modernity. Cambridge: Harvard University Press.

Ohnuma, Reiko. 2007. Head, Eyes, Flesh, and Blood: Giving Away the Body in Indian Buddhist Literature. New York: Columbia University Press.

Olson, Carl. 2015. Indian Asceticism: Power, Violence, and Play. New York: Oxford University Press.

Pittman, Don A. 2001. Toward a Modern Chinese Buddhism: Taixu's Reforms. Honolulu: University of Hawai'i Press. Ritzinger, Justin. 2017a. Anarchy in the Pure Land: Reinventing the Cult of Maitreya in the Modern Chinese Buddhism. New York: Oxford University Press.

Ritzinger, Justin. 2017b. Parsing Buddhist Modernity in Republican China: Ten Contrasting Terms. In Buddhist Modernities: Re-Inventing Tradition in the Globalizing Modern World. Edited by Hanna Havnevik, Ute Hüsken, Mark Teeuwen, Vladimir Tikhonov and Koen Wellens. New York: Routledge, pp. 51-65. 
Scott, Gregory Adam. 2015. Navigating the Sea of Scriptures: The Buddhist Studies Collectanea, 1918-1923. In Religious Publishing and Print Culture in Modern China, 1800-2012. Edited by Philip Clart and Gregory A. Scott. Boston and Berlin: De Gruyter, pp. 91-138.

Scott, Gregory Adam. 2016. Revolution of Ink: Chinese Buddhist Periodicals in the Early Republic. In Recovering Buddhism in Modern China. Edited by Jan Kiely and J. Brooks Jessup. New York: Columbia University Press, pp. 111-40.

Shi, Daoshen 释道申. 1924. Ci shexue xie miaofa lianhua jing fayuanwen 剌舌血寫妙法蓮華經發願文 [The Votive for Extracting Tongue Blood to Copy the Lotus Sutra]. Haichao Yin 159: 391.

Shields, James Mark. 2017. Against Harmony: Progressive and Radical Buddhism in Modern Japan. New York: Oxford University Press.

Shou, Pei 守陪. 1947. Xueshu da fangguangfo huayanjing ba 血書大方廣佛華嚴經跋 [Epilogue to the Blood Writing of the Flower Garland Sutra]. Honghua Yuekan 70: 138.

Taixu 太虛. 1923. Hankou fojiaohui chuangshi jixu 漢口佛教會創始記序 [Prologue for the Founding of Hankou Buddhist Society]. Haichao Yin 4: 223.

Taixu 太虛. 1933. Quan quanguo fojiao qinnian zu huguotuan 勸全國佛教青年組護國團 [Appeal to Buddhist Youths of the Whole Nation to Form a League in Protecting the Nation]. Haichao Yin 184: 15-21.

Teiser, Stephen F. 1988. The Ghost Festival in Medieval China. Princeton: Princeton University Press.

Wang, Jianchuan 王見川. 1999. Zhang Zongzai, Ning Dayun, yu minguo shiqi de fohua xinqinnianhui 張宗載寧 達藴與民國時期的佛化新青年會 [Zhang Zongzai, Ning Dayun, and the Society of New Buddhist Youth in Republican China]. Yuanguang Foxue Xuebao 2: 325-55.

Watson, Burton, trans. 1993, The Lotus Sutra. New York: Columbia University Press.

Weber, Max. 2001. The Protestant Ethic and the Spirit of Capitalism. Translated by Talcott Parsons. London and New York: Routledge.

Welch, Holmes. 1967. The Practice of Chinese Buddhism, 1900-1950. Cambridge: Harvard University Press.

Welch, Holmes. 1968. The Buddhist Revival in China. Cambridge: Harvard University Press.

Wen, Xing 温兴. 1942. Nanjing Xuecan Chuanxin Hande san fashi zhuan 南京學參傳心含德三禪師傳 [Three Biographies of Xuecan, Chuanxin, and Hande in Nanjing]. Foxue Banyuekan 66: 221.

Whalen-Bridge, John. 2015. Tibet on Fire: Buddhism, Protest, and the Rhetoric of Self-Immolation. London: Palgrave Macmillan.

Wu, Yingpei 吳蔭培. 1929. Xueshu huayan jing ba 血書華嚴經跋 [Epilogue for the Blood Writing of the Flower Garland Sutra]. Haichao Yin 172: 324-25.

Xia, Qixuan 夏琦璿. 1923. Fo chengdao ri fayuanwen cixueshu 佛成道日發願文刺血書 [Prayer for Blood Writing on the Enlightenment Day of the Buddha]. Haichao yin 156: 115.

Xianyin 顯蔭. 1923. Xueshu jinggang bore boluomi jing ba 血書金剛般若波羅密經跋 [Epilogue for Blood Copying of the Diamond Sutra]. Haichao Yin 154: 327.

Xiegen 解根. 1921. Tiantong Dizhen dashi zifen ji 天童諦真大師自焚記 [Record of the Self-immolation of Master Dizhen in Tiantong Temple]. Haichao Yin 151: 211-12.

Xue, Yu. 2005. Buddhism, War, and Nationalism: Chinese Monks in the Struggle against Japanese Aggression 1931-1945. New York and London: Routledge.

Yingche 映徹. 1942. Yingche 映徹. 1942. Jinian Fu Jinqiu jushi song 紀念傅近秋居士頌 [The Ode for the Memorial of the Lay Buddhist Fu Jinqiu]. Foxue Banyuekan 66: 177.

Yinguang 印光. 1921. Fu Ding Fubao jushi lun bixiang shu 覆丁福保居士論臂香書 [Reply to Ding Fubao Regarding Burning Incense on Arms]. Foxue Yuekan 19: 142-43.

Yinguang 印光. 1933. Wei cixue xiejing fu Hongyi Lüshi shu 為刺血寫經覆弘一律師書 [Reply to Master Hongyin about Writing Sutra with Blood]. Zhengxin 43: 249-51.

Yinshun 印順. 1973. Daonian Shoupei shangren 悼念守培上人 [Memorial for Master Shoupei]. Huayu xiangyunh 華雨香雲. CBETA. 349a1. Available online: http://cbetaonline.cn/zh/Y0023_026 (accessed on 29 July 2020).

Yu, Jue 余覺. 1919. Yu Jue song yuanseng Shanji shangren xuexie huayan jing bashi yi juan 余覺頌元僧善繼血寫 華嚴經八十一卷. Jueshe Congshu 1: 294-96.

Yü, Chün-fang. 1981. The Renewal of Buddhism in China: Chu-hung and the Late Ming Synthesis. New York: Columbia University Press.

Yu, Qian 喻謙. 1985. Xinxu gaosengzhuan 新續高僧傳 (the New Further Biography of Eminent Monks). In Dazangjing bubian 大藏經補編 [Supplement to the Dazangjing]. Edited by 藍吉 富. Taipei: Huayu chubanshe. 
Yu, Lingbo 于凌波. 1995. Zhongguo Jinxiandai fojiao renwuzhi 中近代佛教人物志 (Biographies of Buddhist Figures in Modern China). Beijing: Zongjiao wenhua chubanshe.

Yu, Jimmy. 2012. Sanctity and Self-Inflicted Violence in Chinese Religions, 1500-1700. New York: Oxford University Press.

Yuanying 圓瑛. 1947. Xueshu huayanjing song bing xu血書華嚴經頌並序 [Ode and Preface to the Blood Copying of the Flower Garland Sutra]. Honghua yuekan 70: 138.

Zanning 贊寧, ed. 988. Song gaoseng zhuan 宋高僧傳 (The Song Biographies of Eminent Monks). CBETA. Available online: http://tripitaka.cbeta.org/T50n2061 (accessed on 29 July 2020).

Zhang, Chuoxian 張拙仙. 1925. Juxing dashi xingye ji 具行大事行業記 [Record of the Passing Away of Master Juxing]. Foyin 45: 473-74.

Zhang, Chunyi 張純一. 1937. Ranshen gongfo zhi Xuecan shangren shu 燃身供佛 至學參上人書 [Burning Body for the Buddha-Letter to Master Xuecan]. Haichao Yin 197: 510.

Zhang, Zhizhe 张志哲, ed. 2006. Zhonghua fojiao renwu dacidian 中佛教人物大 辞典 (Dictionary of Chinese Buddhist Figures). Anhui: Huangshan Shushe.

Zhifeng 芝峰. 1933. Ba Puqin xueshu fahua jing hou 跋普欽血書法華經後 [Epilogue for Puqin's Blood Writing of the Lotus Sutra]. Sichuan Fojiao Yuekan 58: 73.

Zhongjing 鐘鏡. 1935. Cixue shu jinggang bore jing ba 刺血書金剛般若經跋 [Epilogue for Blood Writing of the Diamond Sutra]. Hongfa shekan 24: 311.

(C) 2020 by the author. Licensee MDPI, Basel, Switzerland. This article is an open access article distributed under the terms and conditions of the Creative Commons Attribution (CC BY) license (http://creativecommons.org/licenses/by/4.0/). 